\title{
Stratigraphic Correlation between Subsurface Maastrichtian Digma Formation and Safra Unit from Outcrop Sections, Western Desert of Iraq
}

\author{
Ibrahim Q. Mohammed', Fadhil A. Lawa² \\ ${ }^{1}$ Geochemistry of Sedimentary Rock (Almufeed Co), Baghdad, Iraq \\ ${ }^{2}$ Department of Geology, College Of Science, University of Sulaimani, Sulaimani, Iraq \\ Email: geology@almufeediraq.com,Fadhil.ameen@univsul.edu.iq
}

How to cite this paper: Mohammed, I.Q. and Lawa, F.A. (2017) Stratigraphic Correlation between Subsurface Maastrichtian Digma Formation and Safra Unit from Outcrop Sections, Western Desert of Iraq. International Journal of Geosciences, 8, 1192-1209. https://doi.org/10.4236/ijg.2017.89068

Received: July 3, 2017

Accepted: September 26, 2017

Published: September 29, 2017

Copyright $\odot 2017$ by authors and Scientific Research Publishing Inc. This work is licensed under the Creative Commons Attribution International License (CC BY 4.0).

http://creativecommons.org/licenses/by/4.0/

(c) (i) Open Access

\begin{abstract}
In this work we try to clarify, and correlate between two Maastrichtian aged units, namely Digma and Safra Units from selected sections in western desert of Iraq. Taking in consideration the stratigraphic code of NASCENT (2005), and the results of previous studies, nine criteria have been used for the correlation, as follow: 1- From lithostratigraphic point of view, Digma Formation (Fm.) mostly composed of dark grey to blackish gray, uniform Carbonates-dominated facies, while Safra unit is characterized by light yellowish brown mixed phosphatic-siliceous-siliciclastics and carbonates facies. 2- Digma Fm. is characterized by Benthonic foraminifera assemblages (Bulimmina sp., Siphogerinoides sp. \& Bolivinoides sp.), while Safra phosphatic unit is flourished by macrofossils assemblages and vertebrates (Oyster, fish teeth's and bones). 3- The upper and lower boundaries of the Digma Fm. are conformable, and vice versa for Safra Unit. 4- Illite/Semctite mixed layers-Illite clays assemblage and Glauconitic are predominates in Digma Fm., while Sepiolite-palygorskite-Montmorillonite, are common in Safra Unit, without any Glauconitic mineralization. 5- Digma Fm. slightly influenced by neomorphism and micritization. On other hand, Safra facies extremely influenced by phosphatization, silicification, dolomitization, and neomorphism and carbonate-silica replacement of the original evaporate minerals. 6- The predominated foraminiferal wackestone and mudstone microfacies, within Digma facies associations, mostly indicate deep trough marine condition (Anah Graben). The mixed phosphatic-carbonates (Oyster coquina band) and siliciclastics facies, (occasionally cross laminated), mostly deposited in shallower water depth, on the Arabian platform and distal steepened ramp towards Rutba flanks. 7- Sequence boundary of type one and three is bounded the Safra Unit respectively from upper and lower parts. 8- Continuously deposited Sequence was detected from the parasequences of the Safra facies, and across
\end{abstract}


Maastrichtian/Danian boundary (Trafawi Unit). 9- The paleo-configuration of the basin almost influenced by the reactivity of the Anah basement faults started in the Late Campanian, and combined by shallowing upwards sequences. The conclusion is that, Digma facies can be considered as local facial changes of the Shiranish Formation, while Safra unit can be considered as a lower Member of (L. Maastrichtian-Danian) Jeed Formation, which is coincides with the whole stratigraphic frame work of the Mediterranean segments of the Tethyan phosphatic realm.

\section{Keywords}

Maastrichtian, Digma Formation, Safra Unit, Western Iraq

\section{Introduction}

The Late Cretaceous sedimentary sequence of the western Iraq, is represented by two main different lithological associations: carbonates and phosphatic types. The carbonates-dominate type, with different lithofacies are well-known by three formations and they are, Hartha, Tayarat and Digma formations. Hartha and Tayarat formations are of Late Campanian-Maastrichtian in age, and cropped out in Rutba and extend to subsurface of whole western Iraq. Hartha formation is also characterized by macrofossils of inner shelf [1]. Furthermore, Hartha Fm. in the Studied area, consist of sandy (arenaceous) lithofacies, as well as in Gaara and south Rutba-H3 areas [2]. The main objective of this work to identify the essential dissimilarity between Digma and Safra units as two Maastrichtian confused lithostratigraphic units. Generally the siliciclastic-carbonate lithofacies of Hartha formation mostly represent tidal-lagoon-reefal facies associations [3] [4]. In this study we will subdivided the Hartha Fm. into two sedimentary facies associations: Gaara-Marbat siliciclastic-dolostone facies types and Wadi Houran-Hartha coral-rudist rich carbonate facies types. Digma Formation about $40 \mathrm{~m}$ thick and mostly well-known from drilled wells near Iraq-Syrian Border, and represents the upper most part of Late Campanian-Maastrichtian facies of Anah Graben basin. Mostly consists of fine-crystalline limestone, occasionally argillaceous and marly, with glauconitic-pyrite mineralization as well as phosphate and quartz grains. This unit rich in planktons with low diversity of Maastrichtian benthonic foraminifera [1] [5]. [5] Divided the whole sequence into many biozones, manifested early Late Maastrichtian age of deep outer shelf to upper bathyal depositional environments. [3] Based on detail microfacies and mineralogical analysis, concluded that the local tectonic activity of Anah Graben mostly controls the depositional environment setting, and continental detrital supply. The second dominated-lithology, represent by Maastrichtian phosphatic sediments of western Iraq, and intensively studied by [2]-[10] [14]. The Maastrichtian phosphatic sediments consist of mixed lithofacies such as; phophorite, limestone, dolostone, shale, porcelainite, chert and locally sandstone. These li- 
thofacies are deposited in different depositional setting ranging from tidal channel fill to tidal, lagoon, oyster bank and open platform ramp type. In Trabiel area (west of studied area), the ramp facies change to basinal facies interbedded with slope turbidites facies of basin margin depositional environment, that is most probably controlled by local fault system [3]. The unusual approach by this work to find the stratigraphical and sedimentological, as well as from the basin variations point of views between Digma and Saffra units. Because there are misleading and misunderstanding of the real dissimilarity between them. Accordingly the novelty of this work to separate Safra unit from Digma formation and to considered Safra as New lithostratigraphic unit. Accordingly nine conjugates lines of evidences (lithostratigraphy, biostratigraphy, stratigraphic boundaries, digenesis, clay mineralogy, depositional environments, sequence boundary types, sequence stratigraphic frameworks and sedimentary basin type) all are described, clarified and integrated to shows the differences. Finally, we compare these result as well as previous work based on several outcrops from Gaara-Akashat-H3 (Rutba area) to find any genetic lithostratigraphic relationship between Digma Formation and Maastrichtian phosphatic succession.

\section{Samples and Methods}

The present study is based on 40 cutting samples collected from Anah well-1 (Figure 1) form depth $641.3 \mathrm{~m}$ to $682.1 \mathrm{~m}$. The second sample interval are collected from depth $682.1 \mathrm{~m}$ to $702.9 \mathrm{~m}$. Another samples group are close from the cretaceous/Tertiary boundary also collected from depths $627.6 \mathrm{~m}$ to $641.3 \mathrm{~m}$, representing almost the lower most part Aaliji Fm. X Ray Diffraction (XRD) method have been used to determine the whole mineralogical composition, and their clay mineral fractions by oriented samples and treated by both ethylene glycol and heating to up to $550 \mathrm{C}$, in order to determine the clay minerals composition and whole mineralogy by semi-quantities estimations. In additions to that about eighty 80 thin sections have been prepared for microfacies analysis and fossils identifications to classify the whole lithology into their microfacies and depositional environment based on Dunham and Flugel classifications respectively [11] [12].

\section{Previous Studies}

The pioneers phosphatic studies in Iraq starts by [6], and they considered them as a part of the Late Cretaceous Tayarat Formation. [7] considered these phosphatic successions as part of Tayarat formation and from the subsurface unit as Digma Formation. Later [2] proposed new name, as Jeed Fm. for the Maastrichtian aged phosphatic unit. [8] Study this succession from mineralogical and sedimentological point of views and confirmed the new informal nomenclature and divided the whole sequence into several lithofacies, arranged in sedimentary transgressive-regressive cycles. [9] divided Jeed Formation into two stratigraphic units; the lower unit as Naaja beds and the upper unit as Safra beds, and both of 


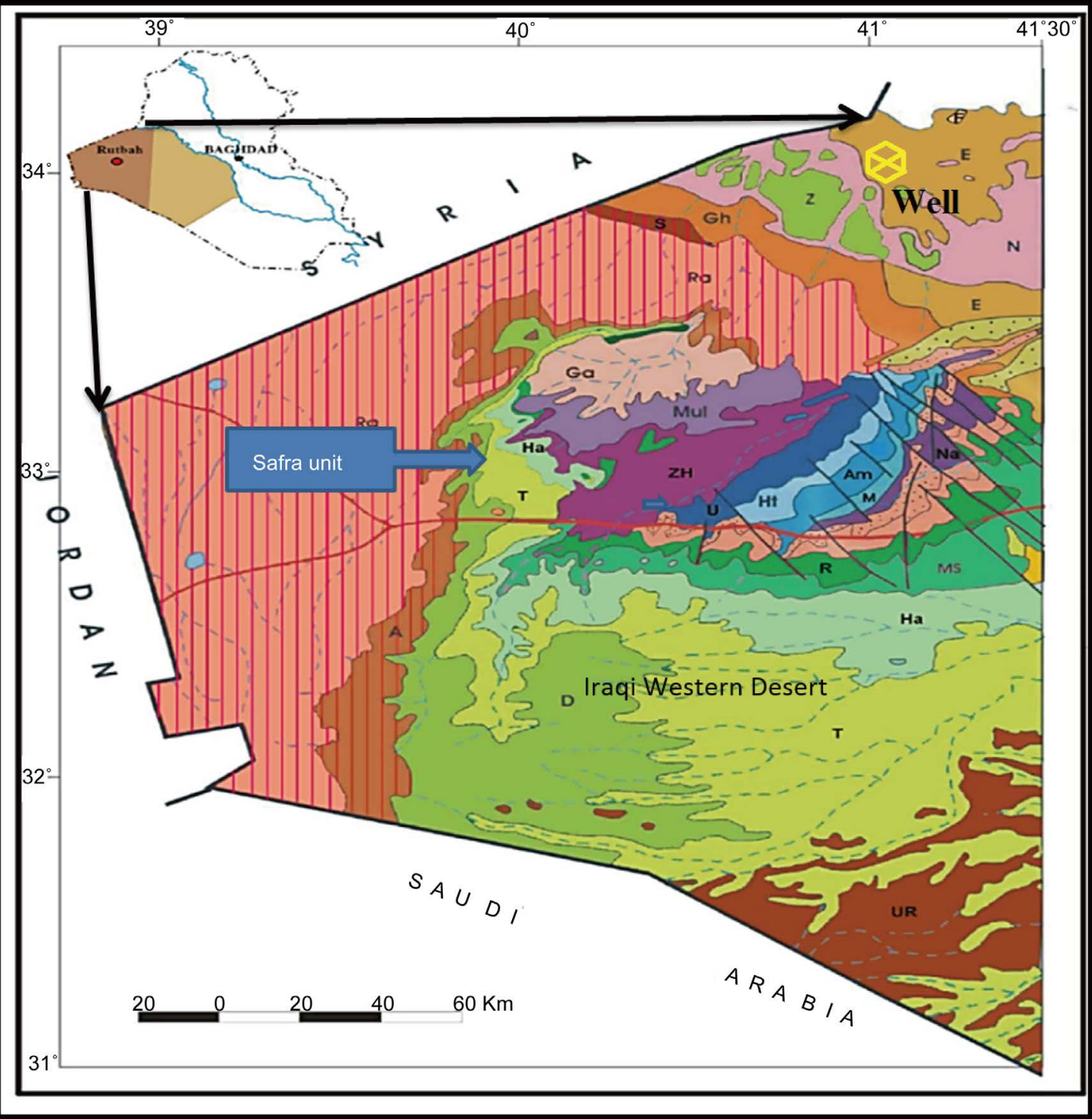

Figure 1. Geological Map of Iraqi western desert [15], including the location map of the Digma formation from Anah well BH-1, and Safra unit outcrops.

them correlated with Marbet beds. [3] in his extensive studies on the exposed and subsurface sections, suggested that, the phosphate bearing unit, almost cut cross the Late Cretaceous-Early Paleogene boundary and they involve the Late Maastrichtian-Danian aged strata. [10] re-used Digma Formation instead of Jeed Formation, which is also followed by several authors [4] [13] [14] [15] [16]. Accordingly in this work we try to clarify that and to identify the main differences between Saffra and Digma formation and, re-arranged those unit based on stratigraphic and sedimentological multicriteria.

\section{Stratigraphic Setting of Digma Formation}

Digma Formation considered as the Early Late Maastrichtian part from the Late Campanian-Maastrichtian sequence of Anah Graben [5], and represent the up- 
per part of Tectonic-Megasequence Arabian Plate Nine (TMSAP.9) by [13] [17] and we follow that in this work. This unit conformably overlies Late Campanian-Early Maastrichtian Pilsner Limestone and underlies Paleocene Aaliji formation. Digma and Pilsner formations westward (towards in southeastern Syria) laterally equivalent and change to Shiranish Formation, as results of the termination of the trough basin of the Anah Graben in whole Euphrates Fault System [18], (Figure 2). This fault bounded intraplate deep basin developed in Turonian, but the vast effect of their active subsidence continued well with thick sediments during Late Campanian-Maastrichtian [19] [20], In western Iraq the subsidence of Euphrates Fault System and Anah Graben moved eastward from older to younger (Hartha Formation replaced laterally by Shiranish Formation in the same boreholes succession) showing tilled fault blocks related with the closure of a new Tethys during Late Cretaceous, when convergence of African-Arabian with European plates [21]. The Arabian plate setting during the Turonian shows great change from extensional phase to compressional phase and associated by the generation of Kurdistan Foreland Basin, north of Iraq [22] The deviation in Anah Graben from extensional to compressional that also associated by variation from normal Faults setting to reverse faults. Such conditions coincide with whole tectonic and stratigraphic setting as in the Arabian platform and mentioned by [17] [23] [24] [25] [26]. They are considered as Pre Arum-unconformity or major Hiatus extends from Turonian and extends to Coniacian to Santonian between Hartha and Rutba-M'Sad, and as Lower boundary of Tectonic Megasequence (TMSAP.9). The graben developed in westernmost part of western Iraq in Late Campanian, is characterized by shallow

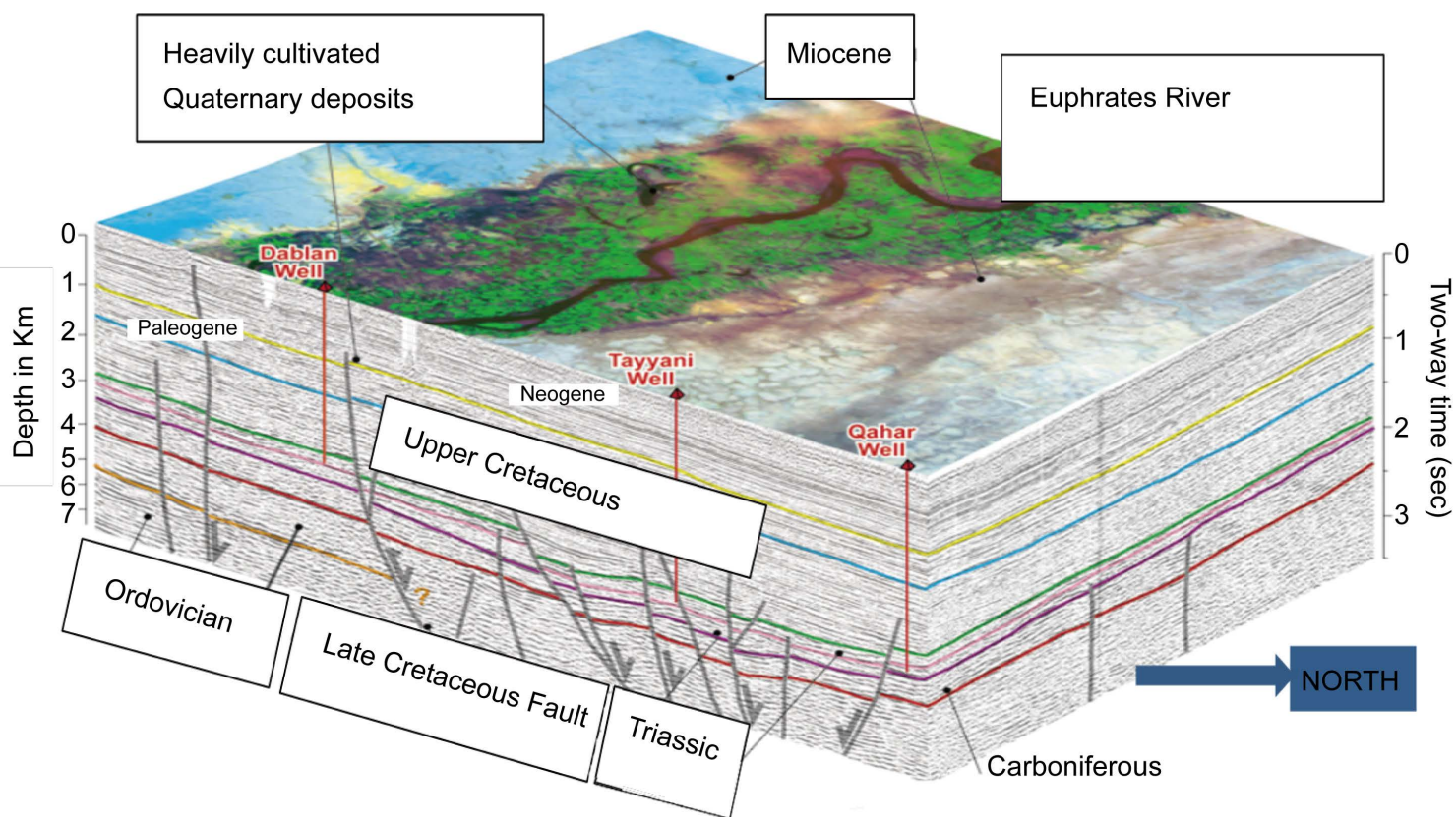

Figure 2. Seismic profile (2D) manifesting the Cretaceous sequences lateral changes in thickness towards Syrian part, below Euphrates River (close from Iraq/Syria Border) and the influence of the Basement faults on the Paleo-configuration of the basin, [after 18]. 
carbonate facies of the Hartha Formation and laterally replaced by basin facies of the Shiranish Formation based on facial changes to predominated planktonic rich marl facies recorded from Anah oil boreholes.

\section{Mineralogy}

The studied samples mainly consist of carbonates with minor amount (10\% $15 \%)$ of other inorganic and organic matter. The carbonate minerals represents essentially by calcite, locally dolomite in minor amount. The calcite mineral almost occur in form of micrite matrix of whole carbonate rocks and forms most of foraminiferal tests, that is locally recrystallized to micro spare or sparites. The clay mineral assemblage are found as Illite/Smectite mixed layer, while Illite was the second clay minerals of low to medium crystallizations. Kaolinite and chlorite are also detected but in minor amount. The majority of clay minerals thought are of detrital origin with minority of diagentic origin (Figure 3(a)). The Quartz mineral recognized from thin sections and XRD tests, as two types, the first one as rounded to surrounded detrital origin as well as chalcedonic chert nodules and microcrystalline quartz; locally filled some foraminifera-land radiolarian chambers. The glauconitic and pyrite minerals are recognized in most studied samples in different proportions. These two minerals are reported in Late Campanian-Eocene sediments of northern and eastern part of Iraq, like Hartha, Shiranish, Tayarat and Jaddala formations. The glauconitic mineralization not detected from phosphatic sediments of western Iraq and equivalent phosphatic formations in Syria, Jordan and Saudi Arabia. The Pyrite mineralization has been recognized in the form of chambers filling of foraminifera, especially Buliminids and Siphogernioids and as fine crystalline grains. The glauconitic minerals are found as dark green peloids and chambers filling. All the petrographic criteria indicate authigenic origin of these two minerals. In the
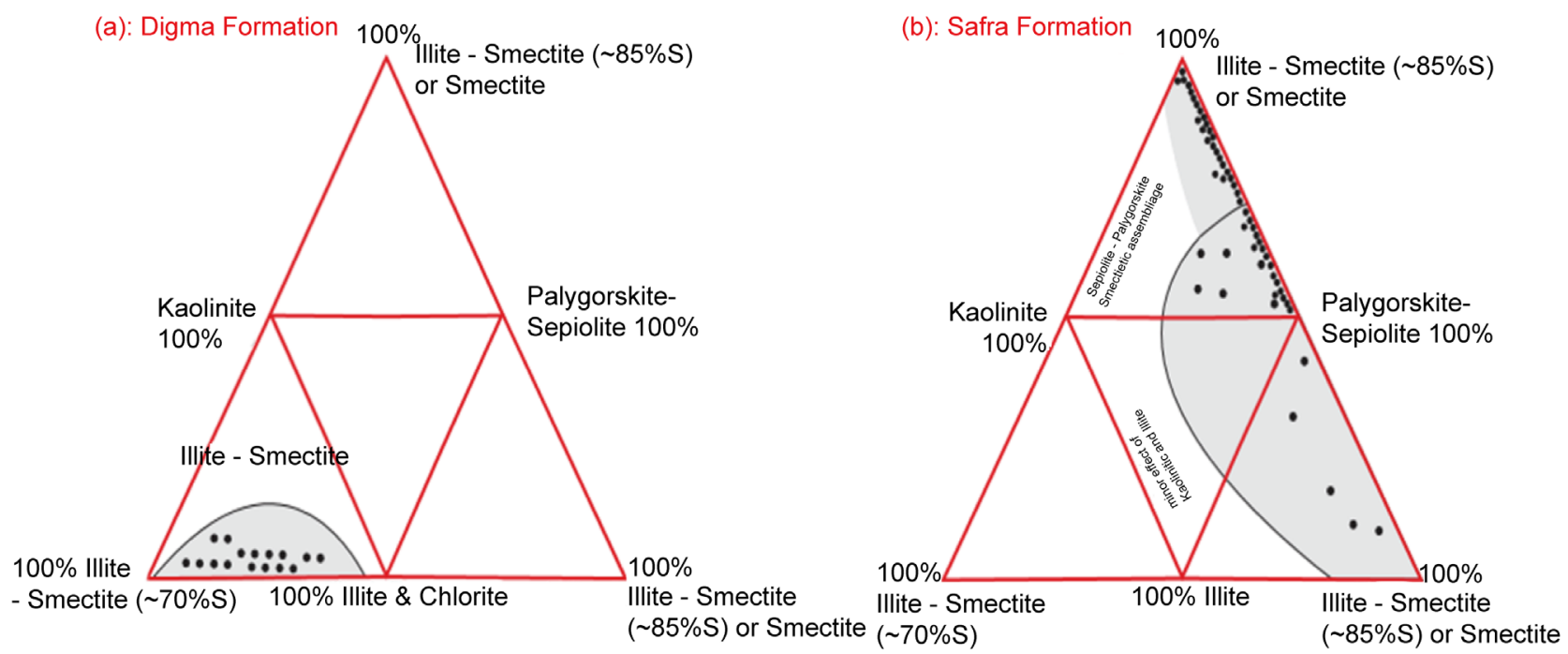

Figure 3. Illite/Smectite mixed layers (I/S $\sim 85 \%)$ or Smectite, Illite/Smectite ( $70 \%$ S), Illite, palygorskite and Sepiolite, Kaolinite clay minerals in relative abundance diagrams for the different rock units. 
phosphatic succession, pyrite only recognized in basin margin facies in Trabial area [3]. Phosphate grains locally present and reach 5\% - 7\% in maximum quantity, in the shape of phosphoclast associated always with quartz and shell fragments of bivalve. The associations of quartz-phosphoclast-bioclastics show positive relationship with clay mineral quantity and possibly transported from near uplifted areas as detrital origin.

\section{Microfacies Analysis of Digma Formation}

For descriptive purpose Digma Formation have been divided into two main lithotypes; Limestone and marly Limestone, which almost reflect uniform lithology of dark gray, fine-crystalline carbonate. Three major microfacies are recognized $\mathrm{A}, \mathrm{B}$, and $\mathrm{C}$ and, $\mathrm{A}$ and $\mathrm{C}$ are further subdivided into five minor submicrofacies as (A1, A2, A3) and (C1, C2). Based on [11] [12] classifications.

A. Mudstone /Wackestone Microfacies. This major microfacies recognized in three sub microfacies types as follow: A1. Foraminiferal Mud/Wackestone submicrofacies. A2. Globogerinal-Radiolarian Mud/Wackestone-submicrofacies. A3. Foraminiferal marly Mudstone-Marl submicrofacies. This Mud/Wackestone Microfacies considered as one of the common microfacies type of the fine-grained limestone in Digma Formation, which is identified from different stratigraphic levels. The main constituents of this microfacies are; planktonic and micro-benthonic foraminifera of medium to low diversity, micrite, organic matter and clay minerals are the matrix of this mud-supported microfacies. The pyrite and glauconitic associated with calcite in minor amount. In A1 submicrofacies, keeled planktons (Globotrucanadis) are associated with globular types as well as micro-benthonic foraminifera like Bulimina and Bolivina (Figure 4(a)). While microfacies A2, shows radiolarian of calcareous chambers, which are abundant in the middle part of the Digma succession (Figure 4(b)). The microfacies A3 showing visible quantity of clay minerals associate with micrite supported keeled and globular planktonic foraminifera, and combined by decreasing of benthonic foraminiferal ratio (Plankton/benthonic $>1$, Figure 4(f)). These microfacies association (A1, and A2,) were deposited in pelagic (A1 \& A2), or hemiplegic (A3) sediments. These facies associations reflect maximum deep outer shelf association and that means maximum flooding surface and maximum accommodation space. The radiolarian rich submicrofacies locally show greater depth of the pelagic outer shelf, but still in calcium carbonate compensation datum depth (CCD). On the other hand, the hemipelagic limestone, indicated by the detrital clay mineral and planktons fertilized in photic zone water.

\section{B. Bioclastic-Foraminiferal Wackestone/Packstone Microfacies}

This microfacies restricted only in the upper most part from Digma Formation, graded from A1-submicrofacies. The main features of this microfacies are the appearance of microspare and dolomite beside micrite matrix. Mud to grain support, high diversity benthonic foraminifera and globular planktons, shell 

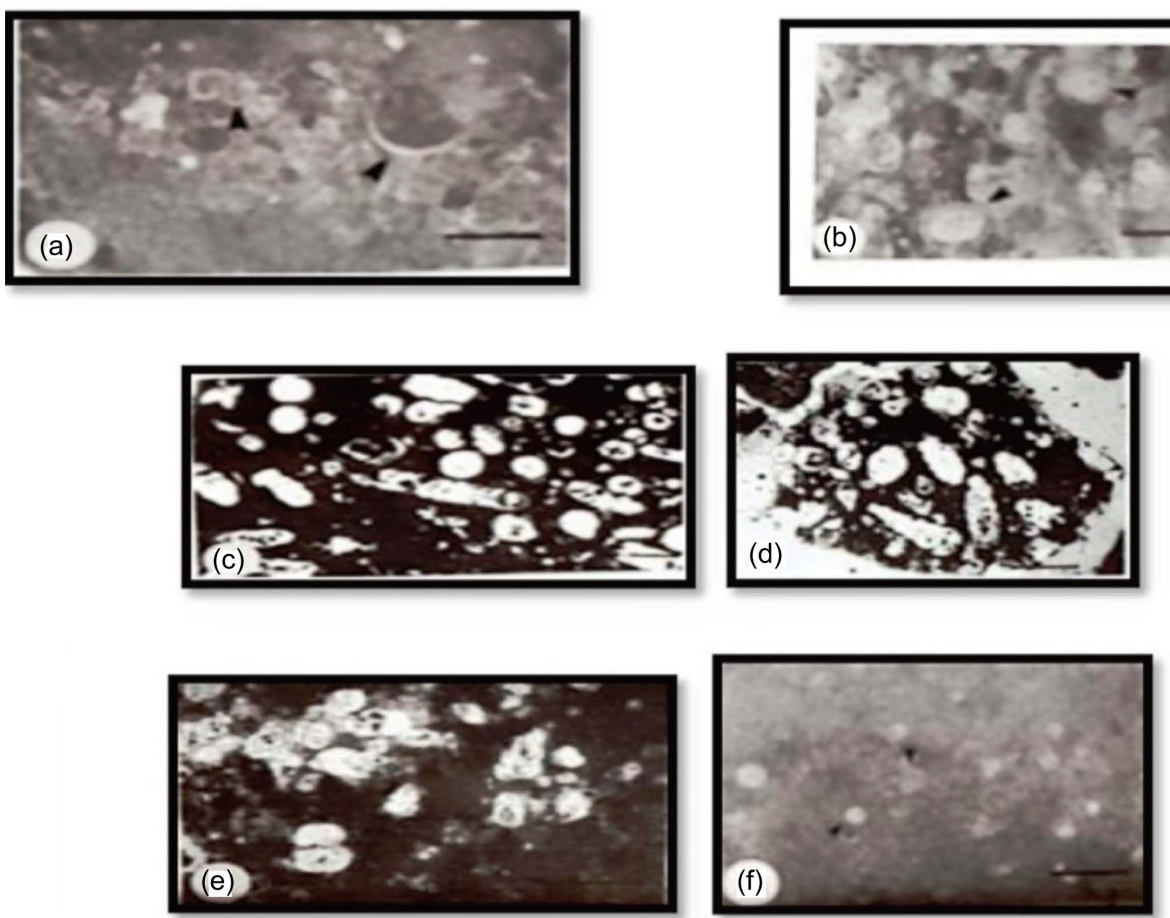

Figure 4. The Major and Minor microfacies of the studied sample. (a) Foraminiferal wackestone, Submicrofacies 4A1, with keeled \& globular planktonic \& micro benthonic foraminifera (Deep outer shelf facies association (b)). Foraminifera and Radiolarian Mud/wackestone (Submicrofacies 4A2) very deep pelagic facies associations. (c) Siphogenerides wackestone Submicrofacies Semiclosed deep graben basin Facies assocaiations. (d) Siphonogenerids and benthonic foraminifera wackestone Semiclosed graben basin, (e) Foraminiferal marly mudstone/Marl Submicrofacies A3 Micritic matrix support with keeled planktonic foraminifera and low benthic foraminifera $(\mathrm{P}>\mathrm{B})$ Deep outer shelf facies associations. (f) Bulimmina rich wackestone (Sub microfacies, Semiclosed deep graben Facies associations. Road scale $=0.2 \mathrm{~mm}$ ).

fragments are fine debris of Ostracodes, echinoids, radiolarian, sponge specials and elongated bivalve shells, these bioclasts mixed with dolomite, quartz, phosphoclasts, glauconitic, pyrite and clay minerals. Micrite and some calcareous fossil chambers show recrystallizations to microspare and fine crystalline dolomite. These allogeneic and authigenic components thought to be a hemipelagic and pelagic mixed environment. Turbidites and probably storm currents transport all allogeneic materials from near uplifted area (horst), as detrital origin to the relatively shallow open shelf. The decreasing of planktonic and increasing benthonic foraminifera with increasing of bioclasts, echinoids, pelecypods debris, indicate shallowing upwards sequence in shallower water depth than microfacies A, and most probably indicates the final regression in Late Maastrichtian.

C. Benthonic foraminiferal Wackestone Microfacies. This microfacies also classified into two subsidiary microfacies as follow: $C 1$. Buliminaceous Wackestone Submicrofacies. C2. Siphogenerinoideous Wackestone submicrofacies. This microfacies is characterized by increasing of benthonic ratio which is become abundant in the upper part from Pilsner Fm. and whole sequence of Digma Fm. 
(Digma Marker beds). This microfacies is predominating in the lower and middle parts of the Digma (Figures 4(c)-(e)). Buliminides and Bolivinoides are the common benthic foraminifera and wide spreads in basinal pelagic and open outer to inner shelf formations of North Africa and Middle East [27] [28] [29] [30]. Buliminides and/or Siphogenerinoides represent about $85 \%$ from whole benthonic forminifera. Other microbenthonic are visible in these two microfacies, Lenticulina sp., and Anomalina sp., as well as planktons of globular chambers. Quartz, phosphate and shell fragments mixed with microbenthonic in mud-support matrix. Pyritation and glauconitization processes are extensive in this microfacies, and possibly indicates very slow rate of depositions.

The abundance of quartz sand and detrital clay minerals in this microfacies are most likely to have been derived from horst uplifted area by turbidity and storm currents. The Pyritation, glauconitization and organic matter associations indicate the limited of oxygenated sediment and the sulfuric condition appeared to be below sediment-water interface. The depleted oxygen condition at the bottom sediments are important factor in the preservation of organic matter and provide geochemical condition for Pyrite and glauconitic mineralization [31]. The oxygen minimum zone as well as organic flux, Salinity, temperature, depth of the depositional basins and climate are important factors provide special environments for low diversity benthonic foraminifera [30]. Buliminides and other low diversity benthonic foraminifera are known for its tolerance to oxygen deficient environment [30] [32]. However [28] Suggested, the high salinity and the closing of the depositional basin, play an important role for this low diversity. Semiclosed seaway basin and development deep depression, maybe related to minor cyclic tectonic re-activities of renewed and quiescent tilting of the Anah Graben in syn-rift tectonic setting. This tectonic pulses creating local sub-basin separated by sills resulting a semi-restricted marine basin, which provide a suitable condition for the accumulation of organic matter in deep quiet circulation sediment-water interface. These geochemical conditions of dyoxic to anoxic muddy seafloor was limited only for some microforaminifera like Buliminides and Siphogerinoides. These microbenthonics are highly tolerant to high food, low oxygen and high sedimentation rates [33]. These facies rich in pyrite, glauconitic, organic matter, dark gray to black colors as well as low diversity microbenthonic ,subordinate quantity of globular planktonic, detrital quartz, shell fragments, phosphatic grains, and increase of clay minerals content, with dolomitization process indicate semiclosed deep inner shelf environment. [5] suggested the low diversity of Buliminids and Siphogerinoides are related to the special condition of phosphatization processes and oxygen depleted at the Digma sedimentary environment. [3] mentioned that their special biological condition recognized not only in Digma Formation, but also in Pilsner Limestone Formation which is phosphate free, suggest the richness of a low diversity community in a local environment, most probably due to the development of semi-closed seaway basin, highly depleted in oxygen. This condition leads to de- 
velopment of a condensate section rich in certain species of foraminifera may be coincides with the maximum flooding surface within the High stand system tract after the main transgression.

\section{Maastrichtian Phosphatic Succession}

The Maastrichtian phosphatic succession of western Iraq, is widely exposed in NE-SW outcrops belt, extend from NE-Gaara Depression, and cutting across Akashat area to the west of Rutba area until Iraqi Saudi borders (Figure 1). The Late Cretaceous-Early Tertiary phosphatic sequence of Iraq, represented the eastern deposit of the giant Tethyan phophorite realm. For this overview, the comparative study depend on studies of Mohammed [3] [8] [34], were high resolutions field work with details sampled and extensive comprehensive lithological, petrographical and mineralogical result as well as fossil and trace fossil content. The studied succession of Safra Beds, consist of different rock types, uncommon in other sedimentary successions. It consists of phophorite, chert, sandstone, dolomite, oyster limestone, shale, porcelainite, and westward fine-grained foraminiferal limestone. The mineralogy of these unique sedimentary rocks show a wide range of mineral composition beside the organic matter which is the black part of the shale, porcelainite, limestone and phophorite beds of west Rutba-H3 and Trabiel subsurface succession. Carbonate (calcite and dolomite), phosphate (carbonate flourapatite). Silica (detrital and chalcedony quartz and opal-CT), gypsum and anhydrite, as well as clay minerals and authigenic silicates (zeolite and feldspar) [35]. Apatite and Opal-CT are characteristic minerals and uncommon in other carbonate formations of Iraq and Arabian Peninsula.

\section{Clay Minerals}

The Palygorskite and sepiolite associated with montmorillonite ( Smectite rich Illite-Smectite mixed layer) clay are the main types of clay minerals, locally kaolinite detected in subordinate quantity with traces of Illite (Figure 3(b)). Palygorskite-sepiolite association are thought to be early diagentic-authigenic origin, where smectitic clay, kaolinite and Illite are detrital in origin. The clay content varies from Zero to about $90 \%$ in industrial shale deposit [3]. The Glauconite is comparatively absent under the microscope, as well as in the results of XRD, IR and electron microscope (SEM and TEM) tests. It's normal like other phosphorite deposits of the North Africa and Mediterranean region except Abu Tartur phosphorite deposits of Egypt (local special case). Where's this mineral are common in non phosphatic carbonate-marl deep outer shelf and trough facies associations of Late Cretaceous-Early Tertiary formations of East Mediterranean Basins, as well as Iraqi shallow and deep carbonate formations (Kometan, Hartha, Shiranish,Tayarat, and Jaddala Formations).

\section{Lithology}

The lithofacies of Late Maastrichtian phosphatic succession (Safra unit) are con- 
sists of sandstone, phosphorite, dolostone-clayeydolostone (marl), dolomitic shale, oyster framestone, Calcitic/siliceous shale, porcelainite, foraminiferal finecrystalline limestone lithofacies. These lithofacies are grouped into four broad facies associations range as follow: 1. Tidal flat facies association (Safra unit-Gaara facies). 2. Innerramp, Oyster-lagoon facies association (Safra unit Akashat-west Rutba facies). 3. Middleramp, open shallow subtidal facies association (Safra unit west Akashat-H3 facies association). 4. Outer ramp-basin margin and turbidity facies association (Safra unit Trabiel facies associations probably fault controlled (3). Generally, the depositional model of the Maastrichtian Safra phosphatic succession is a homoclinal ramp proximal in Gaara zone and near Saudi Arabia border, and distally westwards developed to steepened ramp or as Rimmed platform (Ramp Basin type of the Maastrichtian and Paleocene phosphatic successions of Iraq are first time suggested by [3]. The Si-P-C facies association of Late Maastrichtian of Iraq and other deposits of Tethyan phophorite belt, is a basin of high productivity area effected by strong cold deep upwelling currents [36] [37]. This ramp basin controlled mainly by the western flank of the Rutba uplift. The basin of the Anah Graben was deeper and distal may be affected by cold, deep upwelling currents, which provide minor amount of organic matter accumulations and not enough for phosphatization process like Rutba Basin.

\section{Discussion}

The comparison and correlations between subsurface Digma Formation in northern boundary of the western Desert and age equivalent Late Maastrichtian phosphatic outcrops (extend from NE Gaara to SW Iraqi-Saudi border), are based on conjugates lines of evidences from detail petrography, mineralogy, clay mineralogy, bio-lithofacies and microfacies. These criteria are used as key tools for stratigraphic relationship and sedimentary basin types (Table 1).

These diagnostic stratigraphic criteria provide strong indications, and based on published stratigraphic codes NACSN [38], that they are to belongs to two formations (Safra and Digma facies types, Figure 5).

Digma Formation: This formation represent by fine crystalline limestone and marly (argillaceous) limestone of uniform lithology of pelagic, hemi-pelagic carbonates facies association. Minerlogically the formation mainly consist of calcite with subordinate amount of other minerals (Quartz-Clay minerals, Glauconitic, Pyrite, Dolomite and Apatite). Depend on the clay mineralogy, the formation characterized by Illite/Smectite-Illite assemblage, with glauconitic rich facies. The clay mineral assemblage is recognized also in the underlying Plisner Limestone, and the lower part of the overlying Aaliji formation. The Planktonic and benthonic microforaminifera are the main faunal constituent. The planktons are globular rich, with less abundant of keeled species. Where's the micro benthonic, characterized by two types of populations (A) medium diversity and (B) low diversity. The Low diversity assemblages represented by either 
Table 1. Differences between sediment types and their sedimentary basin of the subsurface Digma Fm. and outcrops Late Maastrichtian phosphatic Safra Member of western part of western Iraq.

\begin{tabular}{|c|c|c|}
\hline Category & Digma formation & Safra member \\
\hline Rock types & $\begin{array}{l}\text { Uniform fine-grained limestone- } \\
\text { marly limestone. }\end{array}$ & $\begin{array}{l}\text { Diverse and multi rock types; phosphorite, chert, sandstone, dolostone, } \\
\text { shale, porcelanite, coquinoidal and fine grained limestone types. }\end{array}$ \\
\hline Rock colors & Gray to black & $\begin{array}{l}\text { Multicolors range from creamy yellow, gray and black in subsurface } \\
\text { only. }\end{array}$ \\
\hline Fossil content & $\begin{array}{l}\text { Planktonic and benthonic foraminifera, } \\
\text { characterized by low diversity (bulimindea or } \\
\text { siphogernoides rich units) }\end{array}$ & $\begin{array}{l}\text { Macrobenthonic, vertebrate bones and teeth, basinword } \\
\text { microforaminifer, sponge spicules and diatoms }\end{array}$ \\
\hline Marker beds & Bulimindea and siphogerioniedes beds & $\begin{array}{l}\text { Oyster beds and spongy rich porcelainite, as well as phophorite } \\
\text { (fish teeth and bones) }\end{array}$ \\
\hline Trace fossil & Absent & Burrows and borings of Thalassinoides tidal type. \\
\hline $\begin{array}{l}\text { Sedimentary } \\
\text { structure }\end{array}$ & Absent & $\begin{array}{l}\text { Oyster or coquina band rich buildups barriers, occasionally } \\
\text { crossbedded oyster framestone and sandstone. }\end{array}$ \\
\hline Cycles & Limestone of high diversity and low diversity cycles. & $\begin{array}{l}\text { Transgressive-Regressive cycles with shallowing upward cycles, locally } \\
\text { with subareial-hard ground exposure surfaces. }\end{array}$ \\
\hline Current types & $\begin{array}{l}\text { Turbidity dominated } \\
\text { (storm local ) }\end{array}$ & $\begin{array}{l}\text { Tidal storm dominated } \\
\text { (turbidity local) }\end{array}$ \\
\hline Mineralogy & Calcite with minor clay minerals, quartz and apatite. & $\begin{array}{l}\text { Calcite, dolomite, apatite, opal-CT, quartz, gypsum, anhydrite, halite } \\
\text { as well as clay minerals }\end{array}$ \\
\hline $\begin{array}{l}\text { Clay mineral } \\
\text { assemblages }\end{array}$ & Illite/Smectite-Illite assemblage, locally kaolinite. & $\begin{array}{l}\text { Palygorskite-sepiolite-montmorillonite assemblage. (Kaolinite } \\
\text { abundant in Gaara and south H3 shoreward facies) }\end{array}$ \\
\hline Glauconite & Abundant & Absent \\
\hline $\begin{array}{l}\text { Authigenic } \\
\text { silicates }\end{array}$ & Absent & Zeolite and feldspar \\
\hline Digenesis & $\begin{array}{l}\text { Limited dolomitization, silicification } \\
\text { And locally microspartization. }\end{array}$ & $\begin{array}{l}\text { Phosphatization, Dolomitization silicification, recrystallization and } \\
\text { sparite cementation. }\end{array}$ \\
\hline Basin controlled & High tectonic activity & Relative sea level fluctuations and low tectonic effect. \\
\hline $\begin{array}{l}\text { Upwelling } \\
\text { currents }\end{array}$ & Weak, carbon rich facies association & Strong, Si-P-C facies association \\
\hline $\begin{array}{l}\text { Sedimentary } \\
\text { environment }\end{array}$ & $\begin{array}{l}\text { Open deep shelf to semi restricted graben basin } \\
\text { type. }\end{array}$ & Coastal (locally fluvial input), inner-outer-ramp. \\
\hline
\end{tabular}

Buliminaceous rich group or Siphogenerinoides rich group, that is recognized in the middle and the upper part of the formation as well as upper part of the Plisner Formation Table 1.

These two microfacies of low diversity benthonic fauna can be used as an important criterion to recognized fault-bounded semi restricted basin in Anah and Euphrates trough, and probably as micro benthonic indicators of a semi-restricted deep fault controlled Anah Graben basins. The sedimentary basin present as open to semi restricted, narrow-elongated trough, was the depositional environment of these facies association and comprised the Southeastern segment of Euphrates Fault System. The Graben developed in East-West trending, $250 \mathrm{Km}$ length and $7-20 \mathrm{Km}$ wide, represented the eastern part from 


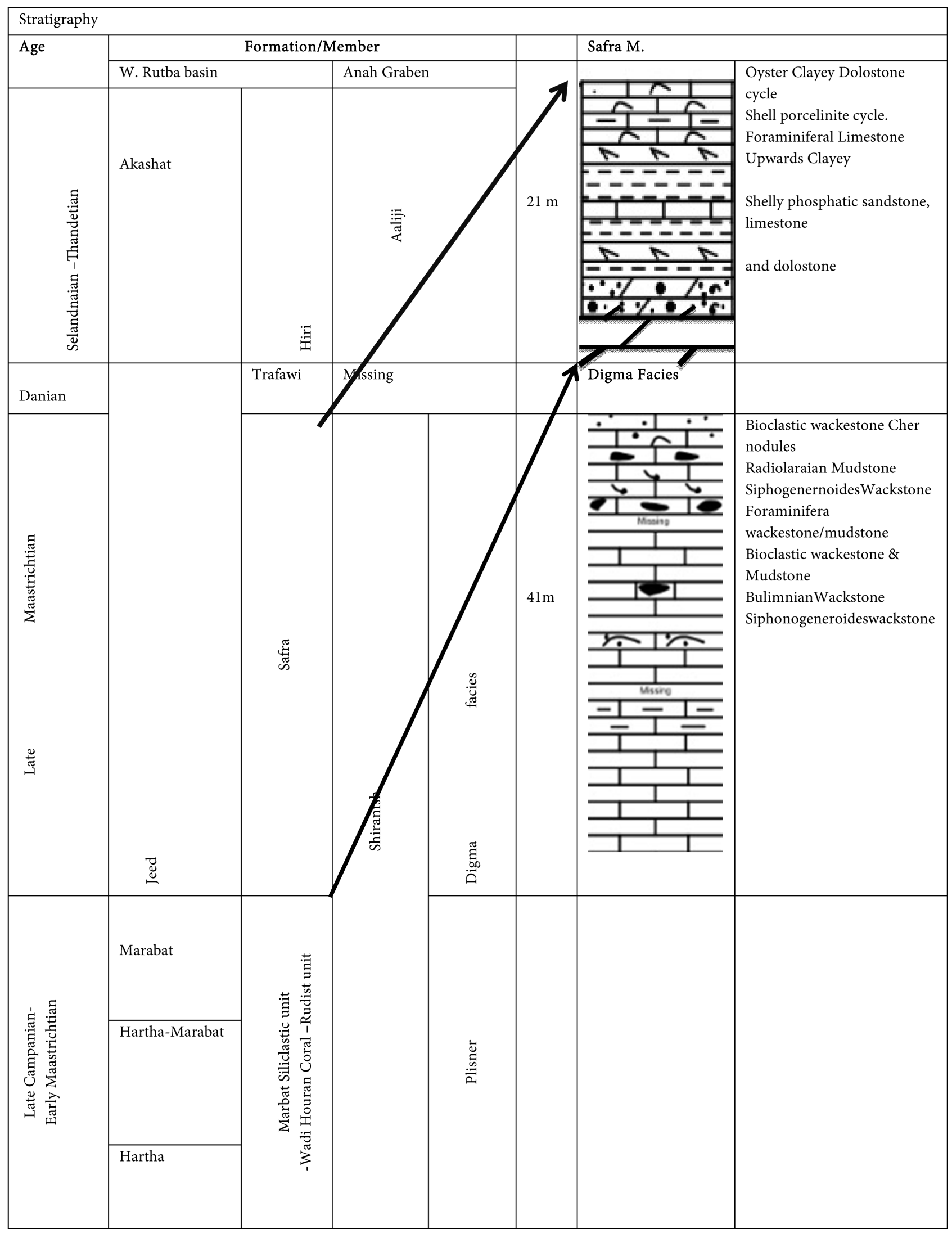

Figure 5. Lithostratigraphic column of Safra member and Digma Fm., (Rutba and Anah Basins). 
NW-SE Euphrates Fault System (Figure 6). Euphrates (including Anah Graben) trough is intercontinental rift basin, formed during the Late Campanian and continues through Maastrichtian time, was subsequently filled by Late Cretaceous syn-rift sediments [1] [19] [20] [21] [39].

\section{Safra Member}

The Maastrichtian phosphatic succession (Safra Member) represented by mixed phosphorite, chert, oyster framestone as well as sandstone, dolostone, fine-grained limestone, shale, porcelainite lithofacies. Minerlogically, these mixed lithofacies reflect a wide range of mineral composition; apatite, dolomite, calcite, quartz, opal-CT, gypsum, anhydrite and clay minerals of palygorskite-sepiolit-montmorillonite assemblage. Macrofossil of oyster and gastropod as well as shark and reptiles bones and teeth are the main index and marker fossils of this succession, basinward micro foraminifera, diatoms, sponge spicules are increase. The succession characterized by Thalassinoides burrows and borings in hard ground surfaces and shallowing upward cycles [8]. Mixed Si-P-C enriched Late Maastrichtian sediments, related with major marine transgression associated with cold, deep upwelling currents from new-Tethys, covered a large area of the western flank of the Rutba uplift .Upwelling currents and locally depositional environments allow the area under the effect of high productivity and formation of these Si-P-C facies association [36]. The depositional model of the Late Maastrichtian (as well as Danian) sedimentary succession, suggested is a homoclinal ramp, shoreward developed to ramp with oyster barrier. Sedimentary basin changed rapidly from homoclinal type to steepened ramp as deep basin margin. These ramp sedimentary facies gradually graded from coastal Gaara facies (Tidal to supratidal association), and oyster bank complex or phophorite

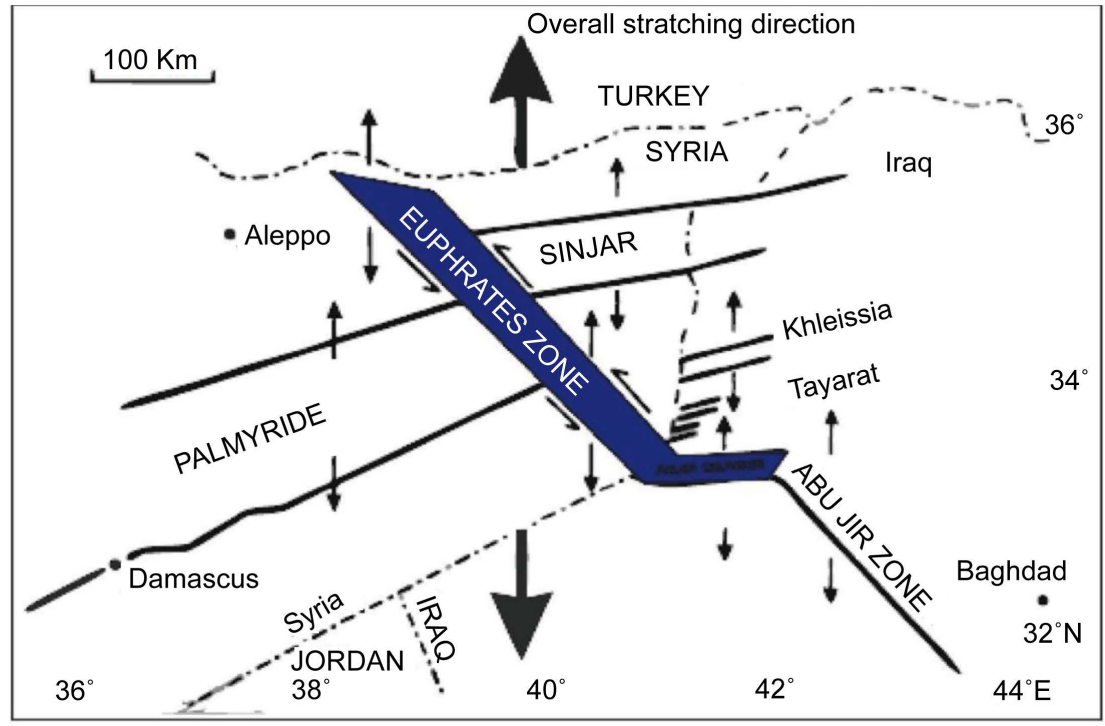

Figure 6. Simplified shetch map illustrating late cretaceous extensions and the formation of the intracontinental rift basins in the Northern Arabian Platform [after 21]. 
sand shoal, to Porcelainite-shale-fine-grained limestone, represented open shallow to deep subtidal ramp. The whole succession and their sedimentary cycles mainly controlled by relative sea level fluctuations and the western flank of the Rutba uplift [40]. We can use Digma and maybe Plisner Limestone formation in Anah basin as a local graben controlled facies of the Shiranish Formation. Shiranish and their Digma and Plisner local facies, are coeval uniform strata of open marine argillaceous chalks-marl deposited in the deep basins in Maastrichtian (Non phosphatic) across the middle East in Syria, Lebanon, Libya, Turkey and Cyprus [41] [42]. Meanwhile, the Late Maastrichtian phosphatic succession cropping out in west flank of the Rutba uplift, showing a high degree of lithologic variability and required to distinguish a separate formation, it need to be named. We suggest using the latest name of this succession: Jeed Formation of the Late Maastrichtian-Danian age, which is represented by two main depositional cycles, Late Maastrichtian Safra Member and Danian Trafawi Member. The lithology of the Jeed Formation is an important succession for the eastern Mediterranean phosphate sequences, which represented the eastern shoreward shallow facies of this giant phosphate deposits in the world (Figure 7).

\section{Conclusions}

1. Based on conjugate line of evidences from sedimentological, and stratigraphic and biostratigraphic with sequence stratigraphic indications, this study acquired that: there are two lithostratigraphic units, one can be named as Safra Member (and considered as the Lower Member of Jeed Formation) and the second as Digma Formation.

2. The facies and fossils content point to two different sedimentary basins with different tectonic settings that separate Digma formation from Safra unit of Jeed

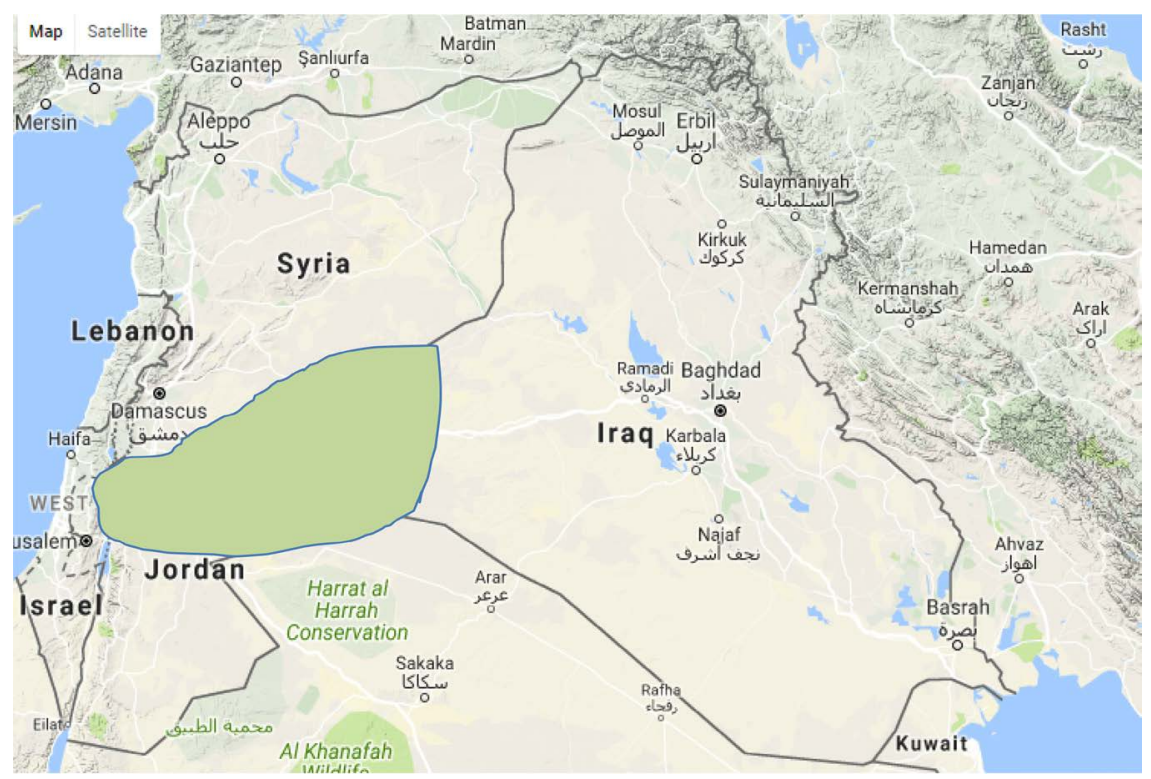

Figure 7. Major phosphorite facies (green color) in the Eat Mediterranean region and its extensions in the studied area [after 37]. 


\section{Formation.}

3. The sediments of the Digma Formation are deposited in Anah Graben and never cropping out in the western part of the western Desert of Iraq and considered as continuations of the deposits within the Euphrates rift basin in Syria.

4. The application of the result of this work can be of high benefit for geological mapping of the western desert of Iraq for multi purposes.

5. Also it's important to mention that Safra unit which is rich in phophorite can be considered as member of Jeed formation accordingly its economic rank will be combined with Jeed Formation and increase its priorities for exploration and productions of phosphatic deposits.

6. Th paleo-configuration of the basin controlled by the rift extensional Arabian platform that is change to reverse fault by the late cretaceous mostly controls the paleogeographic distribution of those phosphatic and non phosphatic facies.

7. There are several lithological similarities between Digma and Shiranish formation, which is already represented the whole lithology of the Euphrates fault bounded basin, ranging in thickness from 200 to $2000 \mathrm{mt}$ in the Euphrates trough Basin.

8. Digma and Shiranish formations are carbonate mudstone-wackestone and marly microfacies. Digma Formation mostly equivalent and correlated with the upper most part of the Shiranish Formation.

9. The phosphatic succession of Iraq and Eastern Mediterranean region is almost always association with bedded phophorite, chert, porcelainite, Shale, coquina limestone in addition with minor chalk and sandstone, and cannot be considered a part of with the fine grained pelagic-hemiplegic Digma Fm.

\section{References}

[1] Bellen, V.R.C., Dunnington, H.V., Wetzel, R. and Morton, D.M. (1959) Lexique Stratigraphique International Asia. Vol. 3, Fasc. 10 a, Iraq, Paris, 333 p.

[2] Jassim, S.Z., Karim, S.A., Basi, M.A., Al-Mubarak, M. and Munir, J. (1984) Final Report on the Regional Geological Survey of Iraq. Vol 3, Stratigraphy. GEOSURV, 1st. Rep. No. 1447.

[3] Mohammed, I.Q. (1993) Mineralogy, Petrology and Depositional Environments of Clays and Siliceous Rocks in the Maastrichtian-Danian Sequence in Western Iraq. PH.D. Thesis, Univ. of Baghdad, Baghdad, 182 p.

[4] Al-Hazaa, S.H. (2001) Basin Analysis of the Upper Cretaceous Sequence in the Western Desert, Iraq. Unpubl. PH.D. Thesis, Baghdad University, Baghdad, 180 p.

[5] Al-Mutwali, M.M. (1992) Foraminifera, Stratigraphy and Sedimentology of the Upper Cretaceous-Lower Tertiary Sediments in Selected Boreholes around Khleisia-Anah-Ramadi Area (Western Iraq). PH.D. Thesis, Univ. of Mosul, Mosul, 268 p.

[6] Antonets, V.B. and Aksenov, S.Y. (1962) Prospecting-Exploration of the Rutba Phosphate Deposit Carried out in 1960-1961 and Reserves Estimation as of January 1st, 1962, Vol. GEOSURV Int. Rep. No. 244.29 p.

[7] Buday, T. and Hak, J. (1980) Report on the Geological Survey of the Western Part of the Western Desert, Iraq. GEOSURV, Int. Rep. 
[8] Mohammed, I.Q. (1985) Petrology and Geochemistry of Upper Cretaceous-Paleocene Phosphatic Rocks in the Rutba-H3 Area, Western Desert Iraq. M.SC. Thesis, University of Baghdad, Baghdad, 267 p.

[9] AL-Bassam, K.S, Karim, S.A., Hassan, K.A., Saeed, L., Yakta, S. and Salman, M, (1990) Report on Geological Survey of the Upper Cretacous-Lower Tertiary Phosphorite Bearing Sequence in the Western Desert Iraq. GEOSURV, Int. Rep. No.2008.

[10] Hassan, K.M. (1998) Palaeoecology and Stratisraphic Distribution of Cretaceous Molluscs, Western Desert Iraq. Unpubl. PH.D. Thesis, Baghdad University, Baghdad $176 \mathrm{p}$.

[11] Dunham, R.J. (1962) Classification of Carbonates Rocks According to Depositional Texture. In: Ham, W.E., Ed., Classification of Carbonate Rocks, Symposium, AAPG, 108-121, 1-7 and 1 Table.

[12] Flugel, E. (2004) Microfacies Analysis of Carbonate Rocks. Springer Verlag, Berlin, 976 p. https://doi.org/10.1007/978-3-662-08726-8

[13] Jassim, S.Z. and Goff, J. (2006) Geology of Iraq. Dolin, Praque, 344 p.

[14] Sissakian, V.K. and Mohammed, B.S. (2007) Stratigraphy; Geology of Iraqi Western Desert. Iraqi Bulletin of Geology and Mining, 51-124.

[15] Sissakian, V.K. and Fouad, S.A. (2015) Geological Map of Iraq. 4th Edition, Iraqi Bulletin of Geology and Mining, 2.

[16] Al-Jibouri, B.S.M. and Gayara, A.D. (2015) Paleocene Sequence Development in the Iraqi Western Desert. Iraqi Bulletin of Geology and Mining, 9, 1-18.

[17] Aqrawi, A.M., Hourbury, A.D., Goeff, G.J. and Sadooni, F. (2010) Petroleum Geology of Iraq. Scientific Press, Ltd., 424 p.

[18] Brew, G., Litak, R., Barazangi, M. and Sawaf, T. (1999) Tectonic Evolution of Northeast Syria: Regional Implications and Hydrocarbon Prospects. Geo Arabia, 4, 289-318.

[19] Litak, R.K., Barazangi, M., Brew, G., Sawaf, T., Al-Iman, A. and Al-Youssef, W. (1998) Structural and Evolution of the Petroliferous Euphrates Graben System, South East Syria. AAPG, 82, 1173-1190.

[20] Caron, C., Maher, J., Zeinab, H. and Cerda, F. (2000) Basin Development and Tectonic History of the Euphrates Graben (Eastern Syria): A Stratigraphic and Seismic Approach. In: Crasquin-Soleau, E., Ed., New Data on Pri-Tethyan Sedimentary Basins, Museum National d'Histoire Naturalle, Vol. 5, 169-202.

[21] Fouad, S.F.A. (2007) Tectonic and Structural Evolution; Geology of Iraqi Western Desert. Iraqi Bulletin of Geology and Mining, 29-50.

[22] Lawa, F.A., Koyi, H. and Ibrahim, A.O. (2013) Tectono-Stratigraphic Evolution of the NW Segment of the Zagros Fold Belt, Kurdistan Region. Journal of Petroleum Geology, 36, 75-96.

[23] Sharland, P.R., Archer, R., Casey, D.M., Davies, R.B., Hall, S.H., Heward, A.P., Horbury, A.D. and Simmons, M.D. (2001) Arabian Plate Sequence Stratigraphy. Geo Arabia Special Publication 2, Gulf PetroLink, Bahrain, 371 p.

[24] Sharland, P.R., Archer, R., Casey, D.M., Davies, R.B., Simmoins, M.D. and Sutcliffe, O.E. (2004) Arabian Plate Sequence Stratigraphy-Revisions to SP2. GeoArabia, 9, 199-214.

[25] Ziegler, M.A. (2001) Late Permian to Holocene Paleofacies Evolution of the Arabian Plate and Its Hydrocarbon Occurrences. GeoArabia, 6, 445-504.

[26] Omar, A.A., Lawa, F.A. and Sulaiman, S.H. (2015) Tectonostratigraphic and Structural Imprints from Balanced Sections across the North-Western Zagros Fold-Thrust 
Belt, Kurdistan Region. Iraq Arabian Journal of Geosciences, 8, 8107-8129.

[27] Alegret, L. and Thomas, E. (2001) Upper Cretaceous and Lower Paleogene Benthonic Foraminifera from North Eastern Mexico. Micropaleontology, 47, 269-316. https://doi.org/10.2113/47.4.269

[28] Butt, A. (1982) Micropaleontol Bathymetry of the Cretaceous of Western Morocco. Palaeogeography, Palaeoclimatology, Palaeoecology, 37, 235-275.

[29] Parsons, D.G. and Brasier, M.D. (1987) Change in Planktonic and Benthonic Foraminifera through Campanian-Maastrichtian Phosphogenic Cycles, Southwest Atlas. In: Hart, M.B., Ed., Micropaleontology of Carbonate Environment, 111-120.

[30] Van Der Zwaan, G.J., Duijinstee, I.A.P., den Dulk, M., Ernst, S.R., Jannink, N.T. and Kouwenhoven, T.J. (1999) Benthonic Foraminifera; Proxies or Problems? A Review of Palaeoecological Concepts. Earth-Science Reviews, 46, 213-236.

[31] Odin, G.S. and Lamaurelle, A. (2001) The Global Campanian-Maastrichtian Stage Boundary. Episodes, 24, 208-229.

[32] Koutsokos, E.A.M. and Merrich, K.A. (1985) Foraminiferal Paleoenvironments from the Barremian to Maastrichtian of Trinidad, West Indies. 1st Geological Conference of the GSTT, 85-101.

[33] Stassen, P., Dupuis, C., Steurbaut, E., Yans, J. and Speijer, R.P. (2012) Perturbation of a Tethyan Coastal Environment during the Paleocene-Eocene Thermal Maximum in Tunisia (SidiNasseur and Wadi Mezaz). Palaeogeography, Palaeoclimatology, Palaeoecology, 317-318, 66-92.

[34] Mohammed, I.Q. (1988) The Lithological and Geochemical Facies Analysis of the Danian Traifawi Montmorillonite Clay Deposit, H3 Area, West Rutba. GEOSURV, Int. Rep.

[35] Mohammed, I.Q. and Al-Rubaie, N.M. (1995) Occurrence of Clinoptilolite-Heulondite Zeolite Minerals in the Maastrichtian, Danian and Eocene Sequences of West and Northwest Iraq. Iraqi Geological Journal, 28, 63-70.

[36] Sheldon, R.P. (1988) A Convection-Current Heat Transfer Model of the Upper Cretaceous-Lower Tertiary Ocean. In: Elevation International Field Workshop and Symposium, Project 156 Phosphorite, 26.

[37] Abed, A.M. (2013) The Eastern Mediterranean Phosphorite Giants; Interplay between Tectonics and Upwelling. Geoarabia, 18, 67-94.

[38] North American Commission on Stratigraphic Nomenclature (NACSN) (2005) North American Stratigraphic Code. American Association of Petroleum Geologists Bulletin, 89, 47-1591.

[39] Lovelock, P.E.R. (1984) A Review of the Tectonics of the Northern Middle East Region. Geological Magazine, 121, 577-587. https://doi.org/10.1017/S0016756800030727

[40] Al-Rawi, Y.T., Mohammed, I.Q. and Al-Bassam, K.S. (1986) Cyclicity in the Upper Cretaceous Phosphates of the Western Desert of Iraq (Abs). 12 th International Sedimentological Congress, Canberra, $342 \mathrm{p}$.

[41] Almogi-Labin, A., Flexer, A., Honigsten, A., Rosenfeld, A. and Rosenthal, E. (1990) Biostratigraphy and Tectonically Controlled Sedimentation of the Mastrichtian in Israel and Adjacent Countries. Rivesta Espanola Paleontologica, 5, 42-52.

[42] Lewy, Z. (1990) Transgression, Regression and Relative Sea Level Change on the Cretaceous Shelf of Israel and Adjacent Countries. A Critical Evolution of Cretaceous Global Sea Level Correlations. Paleoceanography, 5, 619-637. https://doi.org/10.1029/PA005i004p00619 
Submit or recommend next manuscript to SCIRP and we will provide best service for you:

Accepting pre-submission inquiries through Email, Facebook, LinkedIn, Twitter, etc. A wide selection of journals (inclusive of 9 subjects, more than 200 journals)

Providing 24-hour high-quality service

User-friendly online submission system

Fair and swift peer-review system

Efficient typesetting and proofreading procedure

Display of the result of downloads and visits, as well as the number of cited articles Maximum dissemination of your research work

Submit your manuscript at: http://papersubmission.scirp.org/

Or contact ijg@scirp.org 